\title{
Antioxidant and Antimicrobial Activity of Ferulago trojana E. Akalın \& Pimenov
}

\author{
Sevda Süzgeç Selçuk, Nurten Özsoy², Berna Özbek Çelik ${ }^{3}$ Emine Akalın Uruşak ${ }^{4}$ \\ 'Deparment of Pharmacognosy, Faculty of Pharmacy Marmara University, 34668, İstanbul, Turkey \\ 2Department of Biochemistry, Faculty of Pharmacy İstanbul University, 34416, İstanbul, Turkey \\ ${ }^{3}$ Department of Pharmaceutical Microbiology, Faculty of Pharmacy Istanbul University, 34416, İstanbul, Turkey \\ ${ }^{4}$ Department of Pharmaceutical Botany, Faculty of Pharmacy İstanbul University, 34416, İstanbul, Turkey
}

Cite this article as: Süzgeç Selçuk S, Özsoy N, Özbek Çelik B, Akalın Uruşak E (2017). Antioxidant and Antimicrobial Activity of Ferulago trojana E. Akalın \& Pimenov. Istanbul J Pharm 47 (3): 101-106.

\begin{abstract}
Ferulago W. Koch is a genus in the Apiaceae family comprising 34 species, of which 18 are endemic in Turkey. Ferulago species have been known since the time of Dioscorides and have been used in folk medicine for their sedative, tonic, digestive, carminative, and aphrodisiac effects, as well as for the treatment of intestinal worms and hemorrhoids. This study was conducted to evaluate the polyphenolic contents and antioxidant activities of methanol extracts of the aerial parts (HFT) and rhizomes (RFT) of Ferulago trojana E. Akalın \& Pimenov by measuring their ability to inhibit lipid peroxidation induced by Fe ${ }^{3+}$-ascorbate, their DPPH and ABTS + scavenging activities, and their ferric reducing antioxidant power (FRAP value). The methanol extracts were also examined for their antimicrobial activity using the microbroth dilution technique. Results showed that the methanol extracts of the aerial parts of the plant, containing the highest amount of total phenolic content and flavonoids, exhibited antioxidative potential for the chain-breaking inhibition of lipid peroxidation and showed the strongest hydrogen and single electron donor activities, which could thus serve as a free radical scavenger, act as a reductant, and provide protection against oxidative stress. Although the methanol extract of rhizomes did not exhibit any inhibitory effect on lipid peroxidation, it is possible that it might also have protective effects against oxidative damage by scavenging free radicals and acting as a reductant. While both the methanol extracts of the aerial parts and rhizomes of $F$ trojana were effective against Staphylococcus aureus, Methicillin-resistant S. aureus (MRSA), and S. epidermidis, the extracts showed no activity against Escherichia coli, Klebsiella pneumoniae, and Pseudomonas aeruginosa. In addition, the methanol extract of rhizomes of $F$ trojana exhibited antibacterial activity against Proteus mirabilis and antifungal activity against the yeast Candida albicans.
\end{abstract}

Keywords: Ferulago, F trojana, antioxidant activity, antimicrobial activity

\section{INTRODUCTION}

Many medicinal plants and raw extracts, due to their traditional use in vitro antioxidants and antibacterial activities have been screened by many researchers. These activites have been observed on plants containing specially phenolic compounds (Wang et al. 1999; Kähkönen et al. 1999; Pietta 2000; Cushine \& Lamb 2005; Rios \& Recio 2005).

The genus Ferulago (Apiaceae/Umbelliferae) includes 49 species occuring throughout the Northern hemisphere. It is naturally grown mainly in Europe, Northwest and Central Asia, Caucasus, North and Northwest Africa and Turkey. 34 Ferulago species (18 endemic) are naturally grow in Turkey (Peşmen 1972; Davis et al. 1988; Pimenov and Leonov 1993; Özhatay and Akalın 2000; Solanas et al. 2000; Akalın and Pimenov 2004; Kandemir and Hedge 2007).

In different regions in Turkey, Ferulago species are known by different names, as the most common "çakşırotu", "kişniş", "asaotu", "kuzubaşı" ve "kuzukemirdi". Since Dioscorides, Ferulago species are used for the purpose tonic, digestive, carminative, aphrodi- 
siac as well as in the treatment of intestinal worms and hemorrhoids (Baytop 1999; Akalın 1999).

Ferulago trojana is endemic to Mount lda which was first identified in 2004. On ISTE's samples, collected in Çanakkale and Balıkesir, previously determined as F. sylvatica (also this name was specified from same areas in the Flora of Turkey and East Aegean Islands). Later studies showed that they were different from the European sample. The results of the detailed examination of the Turkish 'F. sylvatica' samples, they have been identified as a new species, F. trojana. The species of F. sylvatica is not considered to be in Turkey (Akalın and Pimenov 2004).

To date, there have been some studies on chemical composition of various Ferulago species. Essential oils, coumarins, flavonoids, sesquiterpenes, fatty acids and phytosterols were reported as the chemical constituents of the Ferulago plants. In these studies with respect to the essential oils of Ferulago genus, coumarins, monoterpenes and sesquiterpenes were characterized as the main components (Miski et al. 1990; Doğanca et al. 1991; Yoti\&Assenov 1995; Rustaiyan et al. 1999; Jiménez et al. 2000; Başer et al. ; 2001; 2002; Erdurak et al. 2006; Kilıç et al. 2006; Erdemoğlu et al. 2008; Alkhatib et al. 2009).

In previous study, five compounds have been isolated from F.trojana. From these compounds bergapten, isoimperatorin, 3'-epidecursin and isomaltol are known compounds, isomaltol-3ß-O-glucoside and 3,6-dimethoxy-7-isopropilcoumarin-4-tetradeca-13"-one have been isolated for the first time. Also antioxidant activities and anticholinesterase activities of dichloromethane and methanol extracts of F. trojana were determined (Çakar 2010). GS/MS analysis has resulted in the characterization of 19 compounds representing $99.3 \%$ of the oil with p-cymene (45.8\%) as the main costituents. Monoterpenes and sesquiterpenes were reported from aerial parts of the essential oil of F. sylvatica (Chalchat et al. 1992).

The aim of this study was to evaluate and compare the antioxidant and antimicrobial activities of methanol extracts from the aerial parts (HFT) and rhizomes (RFT) of F. trojana. There are no reports on antimicrobial activity of F.trojana. The most active extract and parts of the plant will be detected and the compounds responsible for the antimicrobial activity in another study will be isolated.

\section{MATERIALS AND METHODS}

\section{Plant material}

Ferulago trojana E. Akalın \& Pimenov a species growing in Turkey was collected from Kaz Dağları (Balıkesir) in June 2007, and identified by Dr. Emine Akalın. A voucher specimen (ISTE No: 74316) is deposited in the Herbarium of Faculty of Pharmacy, Istanbul University (ISTE).

\section{Preparation of extracts}

The dried and powdered aerial parts (30 g) (HFT) and rhizomes (30 g) (RFT) of the F.trojana were percolated with $600 \mathrm{~mL}$ methanol. The methanol extracts were evaporated to dryness under reduced pressure and controlled temperature $\left(45\right.$ to $50^{\circ} \mathrm{C}$ ) in a rotary evaporator. The extracts were lyophilized. The obtained methanol extracts (HFT, RFT) were used for antioxidant and antimicrobial activity determinations.

\section{Chemicals}

Soybean lecithin (L-a-phosphatidylcholine Type IV-S), 2,2-diphenyl-1-picrylhydrazyl (DPPH), quercetin and ascorbic acid were purchased from Sigma Chemical Co. (St. Louis, MO, USA). 2,2'-Azino-bis (3-ethylbenzothiazoline-6-sulfonic acid) diammonium salt $\left(\right.$ ABTS $\left.^{+}\right)$, 6-hydroxy-2,5,7,8,-tetramethylchroman-2-carboxylic acid (Trolox) were purchased from Fluka Chemical Co. (Bushs, Switzerland). Thiobarbituric acid (TBA), trichloroacetic acid (TCA) and ferric chloride were purchased from Merck (Darmstadt, Germany). All other chemicals used were of analytical grade.

\section{Determination of total phenolic compounds}

Total soluble phenolics in the methanol extract of F.trojana were determined with Folin-Ciocalteu reagent according to the method of (Slinkard and Singleton 1977) with some modifications. Aliquots $(0.1 \mathrm{~mL})$ of extracts were transferred into the test tubes and their volumes made up to $4.6 \mathrm{~mL}$ with distilled water. After addition of $0.1 \mathrm{~mL}$ Folin-Ciocalteu reagent (previously diluted 3 -fold with distilled water) and $0.3 \mathrm{~mL} 2 \% \mathrm{Na}_{2} \mathrm{CO}_{3}$ solution, tubes were vortexed and absorbance of mixture recorded after $2 \mathrm{~h}$ at $760 \mathrm{~nm}$ against a blank containing $0.1 \mathrm{~mL}$ of extraction solvent. Gallic acid $(0.05 \mathrm{mg} / \mathrm{mL}-0.4 \mathrm{mg} / \mathrm{mL})$ was used for calibration of a standard curve. The results were expressed as gallic acid equivalents (GAE)/g of extract. The data were presented as the average of triplicate analyses.

\section{Determination of total flavonoid content}

Total flavonoid content was determined by using a colorimetric method described by (Sakanaka et al. 2005). Briefly, $0.25 \mathrm{~mL}$ of the extract $(0.625 \mathrm{mg} / \mathrm{mL}$ extract or $(+)$-catechin standard solution was mixed with $1.25 \mathrm{~mL}$ of distilled water or solvent in a test tube, followed by addition of $75 \mu \mathrm{L}$ of a $5 \%(\mathrm{w} / \mathrm{v})$ sodium nitrite solution. After $6 \mathrm{~min}, 150 \mu \mathrm{L}$ of a $10 \%(\mathrm{w} / \mathrm{v}) \mathrm{AlCl}_{3}$ solution was added and the mixture was allowed to stand for a further $5 \mathrm{~min}$ before $0.5 \mathrm{~mL}$ of $1 \mathrm{M} \mathrm{NaOH}$ was added. The mixture was brought to $2.5 \mathrm{~mL}$ with distilled water and mixed well. The absorbance was measured immediately at $510 \mathrm{~nm}$, using a spectrophotometer (Shimadzu UV-1208). (+)-Catechin standard solution $(15-250 \mu \mathrm{L} / \mathrm{mL})$ was used for the calibration of a standard curve. The results were expressed as means ( \pm $\mathrm{SD}) \mathrm{mg}$ of $(+)$-catechin equivalents per gram of extract.

\section{Antioxidant activity}

\section{Antioxidant activity on liposome peroxidation}

Lipid peroxidation assay was based on the method described by (Duh et al. 1999). Lecithin (300 mg) was suspended in 30 $\mathrm{mL}$ phosphate buffer (10 mmol/L, $\mathrm{pH}$ 7.4). This suspension was then sonicated with a rod using an ultrasonic homogenizer (Bandelin, Berlin, Germany) at 30 s intervals for 10 min until an opalescent suspension was obtained.

The sonicated solution $(10 \mathrm{mg} / \mathrm{mL}), \mathrm{FeCl}_{3^{\prime}}$, ascorbic acid and the extracts (from 0.625 to $10 \mathrm{mg} / \mathrm{mL}$ ) or quercetin (from 0.005 to $0.08 \mathrm{mg} / \mathrm{mL}$ ) used as a reference antioxidant were mixed to produce a final concentration of $3.08 \mathrm{mg}$ liposome $/ \mathrm{mL}, 123.2$ $\mu \mathrm{mol} \mathrm{FeCl}$ and $123.2 \mu \mathrm{mol}$ ascorbic acid. After $1 \mathrm{~h}$ incubation at $37^{\circ} \mathrm{C}$, the formation of lipid peroxidation products was assayed by the measurement of malondialdehyde (MDA) levels on the basis that MDA reacted with TBA at $532 \mathrm{~nm}$ according 
to (Buege and Aust 1978). Briefly, $500 \mu \mathrm{L}$ of this reaction mixture was mixed with $1000 \mu \mathrm{L}$ TCA-TBA reagent (consisting of $15 \% \mathrm{w} / \mathrm{v}$ TCA and $0.375 \%$ TBA in $0.25 \mathrm{~N} \mathrm{HCl}$ ) and $14 \mu \mathrm{L} \mathrm{BHT}$ ( $2 \%$ in absolute ethanol). The mixture was vortexed and heated for 10 min in a boiling water bath. After cooling, an equal volume of n-butanol was added and the mixture was shaken vigorously. The n-butanol layer was separated by centrifugation at $3000 \mathrm{rpm}$ for $5 \mathrm{~min}$. The absorbance of the sample was read at $532 \mathrm{~nm}$ against a blank which contained all reagents except lecithin. The percentage inhibition of lipid peroxidation was calculated by comparing the results of the samples with those of controls not treated with the extract using the following equation: Inhibition effect (\%) = [1-(Absorbance of sample at $532 \mathrm{~nm} /$ Absorbance of control at $532 \mathrm{~nm})] \times 100$.

\section{DPPH radical scavenging activity}

The DPPH radical scavenging activity of the extract was measured according to the procedure described by (Brand-Williams et al. 1995). A $0.1 \mathrm{~mL}$ aliquot of extracts (from 0.16 to $15 \mathrm{mg} / \mathrm{mL}$ ) or quercetin (from 0.01 to $0.16 \mathrm{mg} / \mathrm{mL}$ ) in methanol was added to $3.9 \mathrm{~mL}$ of $6 \times 10^{-5} \mathrm{M}$ methanolic solution of DPPH. The mixture was shaken vigorously and allowed to stand in the dark at room temperature for $30 \mathrm{~min}$. The decrease in absorbance of the resulting solution was then measured spectrophotometrically at $517 \mathrm{~nm}$ against methanol. All measurements were made in triplicate and averaged. Two controls were used for this test, a negative control (containing all reagents except the test sample) and positive controls (using the reference antioxidants). The ability to scavenge DPPH radical was calculated by the following equation:

DPPH radical scavenging activity (\%) $=[1$ - (Absorbance of sample at $517 \mathrm{~nm} /$ Absorbance of control at $517 \mathrm{~nm}$ )] $\times 100$.

\section{Total radical antioxidant potential (TRAP) assay}

The total radical antioxidant potential of the extract was measured using the Trolox equivalent antioxidant coefficient (TEAC) assay as described by (Re et al. 1999) with minor modifications. ABTS was dissolved in water to a $7 \mathrm{mM}$ concentration. ABTS radical cation was produced by reacting $\mathrm{ABTS}^{+}$stock solution with $2.45 \mathrm{mM}$ potassium persulfate (final concentration) and allowing the mixture to stand in the dark at room temperature for 12-16 hours before use. At the begining of the analysis day, an ABTS++ working solution was obtained by the dilution in $96 \%$ ethanol of the stock solution to an absorbance of $0.70( \pm 0.02)$ at $734 \mathrm{~nm}$. After addition of $990 \mu \mathrm{L}$ of ABTS ${ }^{++}$ solution to $10 \mu \mathrm{L}$ of the extracts (from 0.625 to $15 \mathrm{mg} / \mathrm{mL}$ ) or quercetin (from 0.01 to $0.16 \mathrm{mg} / \mathrm{mL}$ ) or trolox standards (final concentration 0 - $20 \mu \mathrm{M} / \mathrm{l}$ ) in absolute ethanol the decrease in absorbance at $734 \mathrm{~nm}$ was monitored exactly 6 min after the initial mixing. Appropriate methanol blanks were run in each assay. All determinations were carried out in triplicate.

The ability to scavenge $\mathrm{ABTS}^{+}$radical was calculated by the following equation: $\mathrm{ABTS}^{+}$radical scavenging activity $(\%)=[1$ - (Absorbance of sample at $734 \mathrm{~nm} /$ Absorbance of control at $734 \mathrm{~nm})] \times 100$.

The total antioxidant capacity value in a sample was assessed as TEAC. The TEAC value was calculated by using a regression equation between the Trolox concentration and the percent- age of inhibition of absorbance at $734 \mathrm{~nm}$ at 6 minutes of incubation and was expressed as mmol TEAC.

\section{Ferric reducing antioxidant power (FRAP) assay}

The FRAP assay was carried out according to the procedure of (Benzie and Strain 1996). The FRAP reagent contained $2.5 \mathrm{~mL}$ of 10 mM TPTZ solution in $40 \mathrm{mM} \mathrm{HCl}$ plus $2.5 \mathrm{~mL}$ of $20 \mathrm{mM} \mathrm{FeCl}_{3} \cdot 6 \mathrm{H}_{2} \mathrm{O}$ and $25 \mathrm{~mL}$ of $0.3 \mathrm{M}$ acetate buffer, $\mathrm{pH}$ 3.6. FRAP reagent $(900 \mu \mathrm{L})$, prepared freshly and incubated at $37^{\circ} \mathrm{C}$, was mixed with $90 \mu \mathrm{L}$ of distilled water and $30 \mu \mathrm{L}$ of the extracts (from 1.25 to $10 \mathrm{mg} / \mathrm{mL}$ ) or quercetin (from 0.02 to $0.31 \mathrm{mg} / \mathrm{mL}$ ) or water for the reagent blank. The increase in absorbance at $593 \mathrm{~nm}$ was measured at 4 min. The standard curve was constructed using iron sulfate heptahydrate solution (125-2000 $\mu \mathrm{M}$ ), and the results were expressed as $\mathrm{mM} \mathrm{Fe}^{2+}$ equivalents. All the measurements were taken in triplicate and the mean values were calculated.

\section{Statistical Analysis}

All measurements were made in triplicate. The results were statistically analyzed using GraphPad Prism version 7.00. Results were considered significant at $\mathrm{p}<0.05$.

\section{Antimicrobial activitiy}

Antimicrobial activity against Staphylococcus aureus ATCC 6538, Staphylococcus epidermidis ATCC 12228, Escherichia coli ATCC 25922, Klebsiella pneumoniae ATCC 4352, Pseudomonas aeruginosa ATCC 27853, Proteus mirabilis ATCC 14153, Methicillin-resistant (MRSA) ATCC 43300 and Candida albicans ATCC 10231 were determined by the microbroth dilutions technique the Clinical Laboratory Standards Institute (CLSI) recommendations (CLSI 2008; 2015). Mueller-Hinton broth for bacteria, RPMI-1640 medium buffered to PH 7.0 with MOPS for yeast strain were used as the test medium. Serial two-fold dilutions ranging from $5000 \mu \mathrm{g} /$ $\mathrm{mL}$ to $4.9 \mu \mathrm{g} / \mathrm{mL}$ were prepared in medium. The inoculum was prepared using a 4-6h broth culture of each bacteria and $24 \mathrm{~h}$ culture of yeast strains adjusted to a turbidity equivalent to a $0.5 \mathrm{Mc}$ Farland standard, diluted in broth media to give a final concentration of $5 \times 10^{5} \mathrm{cfu} / \mathrm{mL}$ for bacteria and $0.5 \times 10^{3}$ to $2.5 \times 10^{3} \mathrm{cfu} / \mathrm{mL}$ for yeast in the test tray. The trays were covered and placed in plastic bags to prevent evaporation. The trays containing Mueller-Hinton broth were incubated at $35^{\circ} \mathrm{C}$ for $18-20 \mathrm{~h}$ and the trays containing RPMl-1640 medium were incubated at $35^{\circ} \mathrm{C}$ for $46-50 \mathrm{~h}$. The Minimum Inhibitory Concentration (MIC) was defined as the lowest concentration of compound giving complete inhibition of visible growth. As control, antimicrobial effects of the solvents were investigated against test microorganisms. According to values of the controls, the results were evaluated.

\section{RESULTS AND DISCUSSION}

\section{Antioxidant activity}

It was reported that the oil, rhizomes, stems, leaves, and flowers of different Ferulago species contain phenolic compounds and show antioxidant activity (Azarbani et al. 2012; Mileski et al. 2015; Dikpınar 2017; Kiziltas et al. 2017).

The results given in Table 1 showed that the amount of extractable phenolic compounds and flavonoids in HFT extract is higher than that detected in RFT extract $(p<0.05)$, so the aerial 
parts of Ferulago trojana is a rich source of phenolics and flavonoids. A similar content of flavonoids was reported by (Kiziltas et al. 2017) for the flowers of Ferulago angulata (Schlecht.) Boiss. (Apiaceae).

The antioxidant activity was tested using four in vitro assays including, lipid peroxidation inhibition, scavenging effect on DPPH and ABTS radicals, and FRAP assays. For comparison, Table 2 presents the results of the antioxidant activities, ex-

\section{Table 1. Total phenolic compounds (PC) las gallic acid equivalents) and total flavonoids (as catechin equivalents) in methanol extracts from $F$ trojana}

\begin{tabular}{|c|c|c|}
\hline Extract & $\begin{array}{c}\mathrm{PC} \\
\text { (mg/g extract) }\end{array}$ & $\begin{array}{c}\text { Flavonoids } \\
\text { (mg/g extract) }\end{array}$ \\
\hline HFT & $64.49 \pm 4.47^{a}$ & $58.89 \pm 4.11^{\mathrm{a}}$ \\
\hline RFT & $6.51 \pm 0.82^{b}$ & $4.56 \pm 0.70^{b}$ \\
\hline \multicolumn{3}{|c|}{$\begin{array}{l}\text { HFT: Aerial parts of } F \text { trojana } \\
\text { RFT: Rhizomes of } F \text { trojana } \\
\text { Values were the means of three replicates } \pm \text { standard deviation. } \\
\text { Values with different letters in the same column were significantly } \\
(p<0.05) \text { different. }\end{array}$} \\
\hline
\end{tabular}

pressed as $\mathrm{EC}_{50^{\prime}}$ TEAC and FRAP values. As can be seen from the $\mathrm{EC}_{50}$ values, the methanol extract of aerial parts showed a higher scavenging effect on DPPH and ABTS radicals, and reducing power when compared to its capability to inhibit lipid peroxidation. TEAC value was similar to the FRAP value, which indicates that the extract is effective in donating of electrons. The aerial parts showed the better antioxidant activity than rhizomes in DPPH and FRAP assays. However, the results showed a weak antioxidant activity of both the extract compared to the referance antioxidant quercetin. Although the extract was less active than the quercetin $(p<0.05)$, it was seen that it has hydrogen and a single electron donor activities, thus could serve as antioxidant.

These results are in accordance with previous studies, which reported the efficiacy of Ferulago species to scavenge free radicals (Azarbani et al. 2012; Mileski et al. 2015; Dikpınar 2017; Kiziltas et al. 2017). Antioxidant activity against lipid peroxidation (LPO) has been reported for the dichloromethane extract of $F$. trojana, which is attributed to the richness of the coumarin in the extract (Çakar, 2010). Çakar (2010) also reported that the pure compounds isolated from the Ferulago trojana (bergapten, isoimperatorin, 3'-epidecursin,

Table 2. $\mathrm{EC}_{50}$, TEAC and FRAP values of methanol extracts from $F$ trojana

\begin{tabular}{|c|c|c|c|c|c|c|}
\hline Extracts & $\begin{array}{c}\text { Lipid } \\
\text { peroxidation } \\
\mathrm{EC}_{50} \\
(\mathrm{mg} / \mathrm{mL})\end{array}$ & $\begin{array}{c}\mathrm{DPPH}^{\mathrm{a}} \\
\mathrm{EC}_{50} \\
(\mathrm{mg} / \mathrm{mL})\end{array}$ & $\begin{array}{c}\text { ABTS }^{\mathrm{a}} \\
\mathrm{EC}_{50} \\
(\mathrm{mg} / \mathrm{mL})\end{array}$ & $\begin{array}{l}\text { Reducing } \\
\text { power }^{\mathrm{a}} \\
\mathrm{EC}_{50} \\
(\mathrm{mg} / \mathrm{mL})\end{array}$ & $\begin{array}{c}\text { Total } \\
\text { Antioxidant } \\
\text { potentialb* } \\
\text { (mM/L TEAC) }\end{array}$ & $\begin{array}{c}\text { FRAP } \\
\text { value } \\
\left.\text { (mM/L } \mathrm{Fe}^{2+}\right)\end{array}$ \\
\hline HFT & $3.01 \pm 0.045^{a}$ & $1.35 \pm 0.069^{a}$ & $1.79 \pm 0.22^{\mathrm{a}}$ & $1.18 \pm 0.34^{\mathrm{a}}$ & $2.15 \pm 0.005^{\mathrm{a}}$ & $1.87 \pm 0.08^{\mathrm{a}}$ \\
\hline RFT & N.d & $16.69 \pm 0.34^{\mathrm{b}}$ & N.d. & $10.73 \pm 0.54^{b}$ & $0.26 \pm 0.03^{b}$ & $0.27 \pm 0.03^{b}$ \\
\hline quercetin & $0.034 \pm 0.006^{\mathrm{b}}$ & $0.069 \pm 0.001^{\dagger}$ & $0.113 \pm 0.002^{d}$ & $0.019 \pm 0.003^{\mathrm{e}}$ & $\begin{array}{c}2.15 \pm 2.42^{\mathrm{a}} \\
\text { (at } 0.16 \mathrm{mg} / \mathrm{mL} \text { ) }\end{array}$ & $\begin{array}{c}2.15 \pm 0.011^{\mathrm{a}} \\
\text { (at } 0.16 \mathrm{mg} / \mathrm{mL} \text { ) }\end{array}$ \\
\hline
\end{tabular}

HFT: Aerial parts of F trojana; RFT: Rhizomes of Ftrojana

${ }^{a} \mathrm{EC}_{50}$ value: The effective concentration at which the antioxidant activity was $50 \%$; DPPH and ABTS radicals were scavenged by $50 \%$ and the absorbance was 0.5 for reducing power. $\mathrm{EC}_{50}$ value was obtained by interpolation from linear regression analysis.

${ }^{b}$ Expressed as mmol Trolox equivalents per gram of dry weight

c Expressed as mmol ferrous ions eqivalents per gram of dry weight

* - Determined at $5 \mathrm{mg} / \mathrm{mL}$

N.d. Not determined

Values were the means of three replicates \pm standard deviation

Table 3. Antimicrobial activities (MIC in $\mathrm{mg} / \mathrm{L}$ ) of methanol extracts from $F$ trojana

\begin{tabular}{|c|c|c|c|c|c|c|c|c|}
\hline $\begin{array}{l}\text { Extracts/ Sta } \\
\text { Pozitive } \\
\text { control } \\
\text { (mg/L) }\end{array}$ & $\begin{array}{l}\text { taphylococcus } \\
\text { aureus } \\
\text { ATCC } \\
6538\end{array}$ & $\begin{array}{c}\text { Methicillin- } \\
\text { resistant } \\
\text { Staphylococcus } \\
\text { aureus } \\
\text { ATCC } 33591\end{array}$ & $\begin{array}{c}\text { Staphylococcus } \\
\text { epidermidis } \\
\text { ATCC } \\
12228\end{array}$ & $\begin{array}{c}\text { Escherichia } \\
\text { coli } \\
\text { ATCC } \\
8739\end{array}$ & $\begin{array}{c}\text { Klebsiella } \\
\text { pneumoniae } \\
\text { ATCC } \\
4352\end{array}$ & $\begin{array}{c}\text { Pseudomonas } \\
\text { aeruginosa } \\
\text { ATCC } \\
1539\end{array}$ & $\begin{array}{l}\text { Proteus } \\
\text { mirabilis } \\
\text { ATCC } \\
14153\end{array}$ & $\begin{array}{c}\text { Candida } \\
\text { albicans } \\
\text { ATCC } \\
10231\end{array}$ \\
\hline HFT & 4.8 & 48 & 78 & - & - & - & - & - \\
\hline RFT & 78 & 19 & 625 & - & - & - & 156 & 312 \\
\hline Cefuroxime- $\mathrm{N}$ & $\mathrm{Na} \quad 1.2$ & nt & 9.8 & 4.9 & 4.9 & nt & 2.4 & nt \\
\hline Vancomycin & nt & 2 & nt & nt & $\mathrm{nt}$ & nt & nt & nt \\
\hline Ceftazidime & nt & nt & nt & $\mathrm{nt}$ & $\mathrm{nt}$ & 2.4 & nt & $\mathrm{nt}$ \\
\hline Klotrimazole & nt & nt & $\mathrm{nt}$ & nt & nt & nt & nt & 4.9 \\
\hline
\end{tabular}


isomaltol, isomaltol-3 $\beta$-O-glucoside and 3,6-dimethoxy7-isopropilcoumarin-4- tetradeca-13"-one) showed antioxidant activity against lipid peroxidation investigated in a $\beta$-carotene-linoleic acid model system, but do not have free radical scavenging ability.

\section{Antimicrobial activitiy}

The antimicrobial activity of F. trojana has been studied for the first time. The antimicrobial activity results of methanol extracts prepared from aerial parts (HFT) and rhizomes (RFT) of F. trojana are shown in Table 3. In this study, both methanol extracts from aerial parts and rhizomes of $F$. trojana showed antibacterial activity against Gram positive bacteria such as S. aureus, MRSA, S. epidermidis while no activity was observed against $E$. coli, K. pneumoniae and $P$. aeruginosa for any of the extracts. Methanol extract from rhizomes of $F$. trojana showed antibacterial activity against $P$. mirabilis and antifungal activity the yeast $C$. albicans. When the results of the antimicrobial activity were evaluated, it was found that the RFT extract showed moderate antimicrobial activity against 4 bacteria and 1 fungal strain while the HFT extract showed activity against three bacterial strains. When compared with positive control results, the best activity was the HFT extract against the $S$. aureus strain with an MIC value of $4.8 \mathrm{mg} / \mathrm{L}$; S. epidermidis with $78 \mathrm{mg} / \mathrm{L}$. It is planned to identify the active compounds and to exhibit antimicrobial activity of the HFT extract.

\section{CONCLUSION}

It was concluded that methanol extract from the aerial parts of the plant, containing the highest amount of total phenolics and flavonoids, has the antioxidative potential for chain-breaking inhibition of lipid peroxidation and shows the strongest hydrogen and a single electron donor activities, thus could serves as free radical scavenger, acts as reductant and provide protection against oxidative stress. Although the methanol extract from rhizomes did not show any inhibitory effect on lipid peroxidation, it may also be expected to protect against oxidative damage by scavenging free radicals and acting as reductant. The results demonstrated the health promoting potential of aerial parts from F. trojana. On the other hand, because of the high antimicrobial activity of the plant, the aerial parts of the plant and its rhizomes could be source of antimicrobial effective new molecules.

\section{REFERENCES}

- Akalın E, Pimenov MG (2004). Ferulago trojana (Umbelliferae), a new species from western Turkey. Bot J Linn Soc 146: 499-504. [CrossRef]

- Akalın E (1999). Taxonomical studies on the genus Ferulago in Western Anatolia. Unpublished PhD Thesis, Istanbul University, Istanbul.

- Alkhatib R, Hennebelle T, Roumy V, Sahpaz S, Süzgeç S, Akalın E, Mericli AH, Bailleul F (2009). Coumarins, caffeoyl derivatives and a monoterpenoid glycoside from Ferulago asparigifolia. Biochem Syst Eco/ 37: 230-233. [CrossRef]

- Azarbani F, Saki Z, Mohammadi A (2012). Phenolic contents, antibacterial and antioxidant activities of flower, leaf and stem extracts of Ferulago angulata (Schlecht) Boiss. Int J Pharm Pharm Sci 6: 123-125.
Başer KHC, Demirci B, Duman H (2001). Composition of the essential oil of Ferulago asparigifolia Boiss. from Turkey. J Essent Oil Res 13: 134-135. [CrossRef]

- Başer KHC, Demirci B, Özek T, Akalın E, Özhatay N (2002). Microdistilled volatile compounds from Ferulago species growing in Western Turkey. Pharm Biology 40: 466-471. [CrossRef]

- Baytop T. Türkiye'de Bitkilerle Tedavi (1999). İstanbul Üniversitesi Eczacılık Fakültesi Yayınları, Nobel Tıp Basımevi, 2.baskı, İstanbul, pp. 348-349.

- $\quad$ Benzie IFF, Strain JJ (1996). The ferric reducing ability of plasma (FRAP) as a measure of "antioxidant power": The FRAP assay. Anal Biochem 239:70-76. [CrossRef]

- $\quad$ Brand-Williams W, Cuvelier ME, Berset C (1995). Use of a free radical method to evaluate antioxidant activity. Food Sci Techno/ 28: 25-30. [CrossRef]

- Buege JA, Aust SD (1978). Lipid peroxidation. Method Enzymol 52: 302-310. [CrossRef]

- Chalchat JC, Garry R, Gorunovic MS, Bogavac PM (1992). Composition of the essential oil of Ferulago sy/vatica (Besser) Reichenb. Pharmazie 47: 10-11

- Clinical and Laboratory Standards Institute (CLSI) (2015). Methods for dilution antimicrobial susceptibility tests for bacteria that grow aerobically: Approved Standard M7-A10. Wayne, Pennsylvania.

- Clinical and Laboratory Standards Institute (CLSI) (2008). Reference Method for Broth Dilution Antifungal Susceptbility Testing of Yeasts; Approved Standart Third Edition. Wayne M27-A3 Wayne, Pennsylvania.

- Cushnie TPT, Lamb AJ (2005). Antimicrobial activity of flavonoids. Int J Antimicrob Agents 26: 343-356. [CrossRef]

- Çakar B (2010). Isolation of secondery metabolites of Ferulago idaea and Ferulago trojana plants, investigation of their antioxidant and anticholinesterase activities. Unpublished MSc Thesis, Istanbul Technical University, Istanbul.

- Davis PH, Mill RR, Tan K (1988). Flora of Turkey and the East Aegean Islands, Vol. 10, pp. 145-154 (Suppl. 1). Edinburgh University Press, Edinburgh.

- DikpınarT (2017). The active constituents isolation from Ferulago trachycarpa Boiss. by antimicrobial activity-guided. Unpublished MSc Thesis, Marmara University, Istanbul.

- Doğanca S, Ulubelen A, Tuzlacı E (1991). 1-Acetylhydroquinone 4-galactoside from Ferulago aucheri. Phytochem 30: 2803-2805. [CrossRef]

- $\quad$ Duh PD, Tu YY, Yen GC (1999). Antioxidant activity of water extract of Harng Jyur (Chrysanthemum morifolium Ramat). Lebensm Wiss Technol 32: 269-277. [CrossRef]

- Erdemoğlu N, Akalın E, Akgöç M, Çıkrıkçı S, Bilsel G (2008). Comparison of the seed oils of Ferulago trachycarpa Boiss. different localities with respect to fatty acids. Rec Nat Prod 2: 13-18.

- Erdurak CS, Coşkun M, Demirci B, Başer KHC (2006). Composition of the essential oil of fruits and roots of Ferulago isaurica Peşmen and F. syriaca Boiss. (Umbelliferae) from Turkey. Flavour Fragr $/$ 21: 118-121. [CrossRef] Jiménez B, Concepción Grande M, Anaya J, Torres P, Grande M (2000). Coumarins from Ferulago capillaris and F. brachyloba. Phytochem 53: 1025-1031. [CrossRef]

- Kähkönen MP, Hopia AN, Vuorela HJ, Rauha J-P, Pihlaja K, Kujala TS, Heinonen M (1999) Antioxidant activity of plant extracts containing phenolic compounds. J Agric Food Chem 47: 3954-3962. [CrossRef]

- Kandemir A \& Hedge IC (2007). An anomalous Ferulago (Apiaceae) from eastern Turkey. Willdenowia 37: 273-276. [CrossRef] Kılıç CS, Okada Y, Coşkun M, Okuyama T (2006). New furanocoumarins isolated from the roots of Ferulago isaurica Peşmen growing in Turkey. Heterocycles 69: 481-486. [CrossRef] 
- $\quad$ Kiziltas H, Eki, S, Bayramoglu M, Akbas E, Oto G, Yildirim S, Ozgokce F (2017). Antioxidant properties of Ferulago angulata and its hepatoprotective effect against $\mathrm{N}$-nitrosodimethylamine-induced oxidative stress in rats. Pharm Bio/ 55: 888-897. [CrossRef]

- Mileski KS, Džamić AM, Ćirić AD, Ristić MS, Grujić SM, Matevski VS, Marin, PD (2015). Composition, antimicrobial and antioxidant properties of endemic species Ferulago macedonica Micevski \& E. Mayer. Rec Nat Prod 9: 208-223.

- Miski M, Moubasher HA \& Mabry TJ (1990). Sesquiterpene aryl esters from Ferulago antiochia. Phytochem 29: 881-886. [CrossRef]

- Özhatay N, E Akalın (2000). A New species of Ferulago W.Koch (Umbelliferae) from North-west Turkey. Bot J Linn Soc 133: 353342. [CrossRef]

- $\quad$ Peşmen H (1972). Ferulago W.Koch In: Davis PH (ed), Flora of Turkey and the East Aegean Islands, Vol.4: 453-471, Edinburgh University Press, Edinburgh.

- $\quad$ Pietta P-G (2000). Flavonoids as antioxidants. J Nat Prod 63: 10351042. [CrossRef]

- Pimenov MG, Leonov MV (1993). The Genera of the Umbelliferae, A Nomenclator. London: Royal Botanic Gardens Kew.

- Re R, Pellegrini N, Proteggente A, Pannala A, Yang M, Rice-Evans C (1999). Antioxidant activity applying an improved ABTS radical cation decolorization assay. Free Radical Bio Med 26: 1231-1237. [CrossRef]

Rios JL \& Recio MC (2005). Medicinal plants and antimicrobial activity. J Ethnopharmaco/ 100: 80-84. [CrossRef]

- Rustaiyan A, Yari M, Masoudi S, Aghjani Z (1999). Chemical constituents of the essential oil of Ferulago contracta Boiss \& et Hausskn., a species endemic to Iran. J Essent Oil Res 11: 609-610. [CrossRef]

Sakanaka S, Tachibana Y \& Okada Y (2005). Preparation and antioxidant properties of extracts of Japanese persimmon leaf tea (kakinoha-cha). Food Chem 89: 569-575. [CrossRef]

Slinkard K \& Singleton VL (1977). Total phenol analysis: automation and comparison with manual methods. Am J Enol Viticult 28: 49-55.

- Solanas JL, Crespo MB \& Martin FG (2000). Una nueva especie Iberica de Ferulago Koch (Apiaceae). Anales del Jardín Botánico de Madrid 58: 101-107 (in Spanish with English abstract). [CrossRef] - Yoti MJ \& Assenov I (1995). Phyrochemical studies on Ferulago sylvatica. Fitoterapia 66: 88-89.

- Wang M, Shao YLJ, Zhu N, Rangarajan M, LaVoie, EJ, Ho CT (1999). Antioxidative phenolic glycosides from Sage (Sa/via officinalis). J Nat Prod 62: 454-456. [CrossRef] 